\title{
Ortaokul Matematik Ders Kitaplarında Yer Verilen Matematik Tarihi İçeriklerinin İncelenmesi
}

\author{
Examination of Mathematical History Contents in Middle School \\ Mathematics Textbooks
}

\author{
Lütfi İNCIKABI ${ }^{1}$, İbrahim KEPCEOĞLU², Uğur KÜÇÜKOĞLU ${ }^{3}$
}

• Geliş Tarihi: 13.06.2018 • Kabul Tarihi: 10.09.2018 • Yayın Tarihi: 01.01.2019

\begin{abstract}
$\ddot{O} \mathbf{z}$
Matematik eğitimine verilen öneme rağmen, birçok öğrenci matematiğin kurallardan, formüllerden, anlaş1lamayan sembol ve işaretlerden oluştuğunu düşünmektedir. Öğrencilerde var olan bu düşünceyi değiştirmek amacıyla birçok araştırmacı tarafından öne sürülen görüşlerden biri de matematik eğitiminde matematik tarihini kullanmak olmuştur. Öğrencilerin matematik tarihi ile ilgili bilgilere ulaşmasının en kolay yolunun sahip oldukları ders kitapları olduğu düşünüldüğünde bu çalışmanın amacı, 2016-2017 yılında kullanılan ortaokul matematik ders kitaplarının içerdiği matematik tarihi ögelerinin içeriklerinin ve kullanım yollarının belirlenmesidir. Bu amaçla, okutulan ders kitapları, üç uzman tarafından incelenerek, elde edilen veriler analiz edilmiș ve tablolar halinde sınıflandırılarak gösterilmiștir. Çalı̧̧manın sonucunda, MEB yayınlarında kullanılan matematik tarihi ögelerinin özel yayınlarda kullanılanlardan daha fazla olmasına rağmen, kitap başına düşen matematik tarihi öge sayısının, oldukça az olduğu görülmektedir. Kullanılan matematik tarihi ögelerinin de belli öğrenme alanlarında yığıldığı belirlenmiştir. Gelişen teknoloji ve bilgiye ulaşım yollarının arttığı çağımızda, internet kaynaklı matematik tarihi bilgilerine ders kitaplarında daha fazla yer verilmesi, ders kitaplarında kullanılan matematik tarihi öge sayısının artması çalışmanın sonucu olarak önerilmiştir.
\end{abstract}

Anahtar sözcükler: matematik tarihi, ders kitapları, ortaokul.

\begin{abstract}
Despite the fact that mathematics education is very important in all countries, many students think that mathematics is consisted of rules, formulas, symbols and signs. The use of history of mathematics is suggested by many researchers to change this belief in students. As textbooks are primary resources for students to gain information on the history of mathematics, the aim of this study is to determine the content and use of the mathematical history items contained in the secondary school mathematics textbooks used in 2016-2017. For this purpose, the textbooks are examined by three experts and the obtained data are analyzed and classified. Although the number of mathematical history items used in textbooks published by is high than the ones in private publishing companies, it is revealed that there are a few mathematical historical items per book. Also, it has been determined that these items are piled up in certain learning areas. As the way of developing technology and information is getting faster, more internet based mathematical history information should be given in the textbooks, and total items should be increased.
\end{abstract}

Keywords: history of mathematics, textbooks, elementary mathematics education.

\section{Önerilen Atıf Bilgisi:}

İncikab1, L., Kepceoğlu, İ. ve Küçükoğlu, U. (2019). Ortaokul matematik ders kitaplarında yer verilen matematik tarihi içeriklerinin incelenmesi. Pamukkale Üniversitesi Eğitim Fakültesi Dergisi, 45 , 144-158.

\footnotetext{
1 Doç. Dr., Kastamonu Üniversitesi, ORCID:/0000-0002-7912-780X, lutfiincikabi@yahoo.com,

2 Dr. Öğr. Üyesi, Kastamonu Üniversitesi, ORCID:0000-0002-5772-0987, ikepceoglu@kastamonu.edu.tr,

${ }^{3}$ Yüksek lisans öğr., Kastamonu Üniversitesi, ORCİ:0000-0003-3329-3121, kucukoglugur@gmail.com,
} 


\section{GíRiş}

İnsan deneyiminin bir parçası olan matematiğin, günlük yaşamın pratik ihtiyaçlarını karşılamak, kişisel ilgi ve merakı gidermek için doğduğu söylenebilir (Yıldırım, 2008). Yapısı itibariyle bütün insanlığın üzerinde anlaşabileceği bir dile sahip olan matematik, insanlığın ulaştı̆̆ bütün büyük başarıların ve teknolojik gelişmelerin temelinde yer almaktadır (Guillen, 2010). Bu sebeple birçok ülke, matematik eğitimine önem vermekte, öğrencilerinin temel matematik becerilerini geliştirmekle birlikte, onların analiz, sentez, eleştirel düşünme ve inovatif düşünme gibi becerilerinin de üst seviyede olmasını istemektedir (Yıldırım, 2008; Baki, 2008).

Matematik eğitimine verilen bu önem ve yapılan çalışmalara rağmen birçok öğrenci için matematik hala anlamsız kurallardan, şekillerden ve sembollerden ibarettir (Tözluyurt, 2008; Sertöz, 2002; Dursun \& Dede, 2004). Öğrencilerin çoğu matematiği günlük hayatla ilişkilendirememekte, matematik yapmanın gerçek hayatta faydasının olmayacağını düşünmekte, sadece iyi bir akademik hayat için matematik sınavlarından yüksek not almak gerektiğini düşünmektedir (Özgün-Koca ve Şen, 2006). Birçok araştırmacı, yaptıkları çalışmalarla matematik tarihinin, öğrencilerin sahip olduğu bu olumsuz tutumu değiştirebileceğini söylemektedir (Rosa, 2013; Shara, 2013; Swetz, 1994; Gulikers ve Blom, 2001; Gürsoy, 2010; Liu, 2003; Marshall, 2000; NCTM, 1998; Yıldız, Kanbolat ve Baki, 2010; Jankvist, 2009; Siu \& Tzanakis, 2004; Nasibov \& Kaçar, 2005). Matematik tarihi, matematiğin yıllar boyunca nasıl geliştiğini ve medeniyetler arası nasıl el değiştirdiğini gösteren bir alandır (Baki, 2014). Dolayısıyla araştırmacılar, derslerde matematik tarihini kullanarak, öğrencilerin matematiğe karşı olan tutumlarının değişebileceğini, akademik başarılarının artabileceğini, öğrencilere matematiğin gökten inen bir kurallar bütünü olmadığını göstereceğini belirtmişler ve matematik tarihinin matematik öğretiminde kullanılmasını önermişlerdir (Baki, 2008; Wilson \& Chauvot, 2000; Albayrak, 2011; Jankvist, 2009; Tözlüyurt, 2008; Yenilmez, 2011). 2013 yılında değişen ortaokul matematik dersi programında da matematik tarihinin öneminden bahsedilmiş, öğrencilerin tarihteki önemli matematikçilerin hayatlarından haberdar olmalarının önemine vurgu yapılmıştır.

Matematik tarihinin matematik eğitimindeki önemi, öğrencilerin bu alanla ilgili bilgilere nasıl ulaşacağı sorusunu akla getirmektedir. Bütün öğrencilerin, matematik tarihi ile ilgili bilgilere ulaşabileceği en kolay ve en ucuz yol, öğrencilerin hepsinin sahip oldukları matematik kitaplarıdır. Alkan (1979), ders kitaplarının hem öğrenci çalışma gereçleri arasında yer alması hem de öğretmen-öğrenme süreçleri içerisinde yer alması sebebiyle en çok kullanılan ders aracı olduğundan özel bir öneme sahip olduğunu belirtmektedir. Ders kitapları, öğretmenin dersin amaçlarını belirlemesinde, kullanılacak stratejilere, yöntem ve tekniklere karar vermesinde, sınıf içinde uygulayacağı öğretme faaliyetlerine karar vermesinde de önemli bir rol oynamaktadır (Yalın, 1996). Öğretmenler kendileri için belirlenen ders kitaplarını derslerin işlenişini şekillendirmek için kullanırlar (Koçyiğit ve Pektaş, 2017). Dolayısıyla matematik ders kitaplarındaki matematik tarihi bilgileri, öğretmenler ve öğrenciler için oldukça önemlidir. Ders kitaplarında yer alan bu bilgiler ile öğrencilerin derse karşı olan meraklarının artması sağlanabilir, öğrencilerin bu bilgileri araştırması sağlanarak, matematik bilimiyle ilgili kültür sahibi olmaları sağlanabilir.

Bu çalışmanın amacı 2016-2017 eğitim öğretim yılında Milli Eğitim Bakanlığı Talim Terbiye Kurulu tarafindan ortaokullarda okutulması planlanan ortaokul matematik ders 
kitaplarında yer alan matematik tarihi ögelerini iki farklı yol ile analiz etmek ve ders kitaplarında yer alan matematik tarihi ögelerini çeşitli açılardan inceleyerek bu ögelerin sınıflandırılmasını yapmaktır. Bu amaçla "2016-2017 yılında okutulan ortaokul matematik ders kitaplarında matematik tarihi ögelerine ne şekilde yer verilmektedir?" ve "2016-2017 yılında okutulan ortaokul matematik ders kitaplarında matematik tarihi ögelerine yönelik verilen bilgi, açıklama ve örnek uygulamalar ne şekildedir?” sorularına cevap aranmıştır.

\section{Yöntem}

\section{Araştırmanın Modeli}

Çalışmanın amacı ders kitaplarının incelenmesini etraflıca yapmak ve açıklamak olduğundan betimsel analiz yaklaşımlarından içerik analizi kullanılmıştır. Temel amacın toplanan verileri açıklayabilecek kavramalara ve ilişkilere ulaşmak olduğu içerik analizi birbirine benzeyen verileri, belirli kavramlar ve temalar çerçevesinde bir araya getirmek ve bunları okuyucunun anlayabileceği bir biçimde organize ederek yorumlamaktır (Yıldırım ve Şimşek, 2006).

\section{İncelenen Dokümanlar}

Doküman incelemesinde Talim ve Terbiye Kurulu Genel Müdürlüğünün 2016-2017 eğitimöğretim yılı için yayınladığı okutulması gereken 5. , 6. , 7. ve 8. sinıf ortaokul matematik ders kitapları incelenmiştir. İncelen ders kitapları ve hangi yayın evine ait oldukları Tablo 1'de gösterilmiştir.

\section{Tablo 1. Çalışmada incelenen ders kitapları}

\begin{tabular}{lcc}
\hline Sinıf & Kitap Sayıs1 & Yayın Evi/Evleri \\
\hline 5. Sinıf & 2 & MEB ve Özgün Yayınları \\
\hline 6. Sinıf & 2 & MEB ve Sevgi Yayınları \\
\hline 7. Sinıf & 1 & Ada Yayınevi \\
\hline 8. Sinıf & 1 & Sevgi Yayınevi \\
\hline
\end{tabular}

\section{Verilerin Analizi}

Verilerin analizi yapılırken iki farklı araştırmadan yola çıkılarak Tzanakis ve Arcavi (2000)'nin önerdiği Tablo 2'deki sinıflandırma ve Erdoğan vd. (2015)'nin önerdiği ekolojik analiz yöntemine uygun Tablo 3'teki sınıflandırma kullanılmıştır. Bu sınıflandırmalara uygun farklı kodlamalar belirlenmiştir. Kodlamalar tarihsel ögelerin içerikleri, kullanım amaçları ve kullanım yerleri bakımından analiz edilmiştir. Tzanakis ve Arcavi (2000)'nin çalışmasında matematik tarihinin öğretim ortamında kullanımında belirledikleri on üç farklı yol Tablo 2'de görülmektedir. Erdoğan vd. (2015) yaptıkları çalışma ile matematik tarihi ögelerinin ders kitaplarındaki kullanımlarını Tablo 3'teki gibi 4 farklı yolla belirledikleri görülmüştür. 
Ortaokul Matematik Ders Kitaplarında Yer Verilen Matematik Tarihi İçeriklerinin İncelenmesi

Tablo 2. Tzanakis ve Arcavi (2000)'ye göre sınıflandırma

\begin{tabular}{l}
\hline Tarihsel ufak parçalar \\
\hline Deneysel matematik etkinlikleri \\
\hline İnternet \\
\hline Çalışma yaprakları \\
\hline Tarihsel paketler \\
\hline Tarihsel problemler \\
\hline Mekanik araçlar \\
\hline Tarihsel metinler üzerine dayalı araştırma projeleri \\
\hline Oyunlar \\
\hline Filmler ve Diğer görseller \\
\hline Okul dışı deneyimleri \\
\hline Birincil kaynaklar \\
\hline Matematikçilerin yaptıkları hatalardan yararlanma \\
\hline
\end{tabular}

Tablo 3. Erdoğan, Eşmen ve Fındık (2015)'a göre sınıflandırma

\begin{tabular}{l}
\hline Tarihsel notlar \\
\hline Matematiğin kullanım alanlarına ilişkin notlar \\
\hline Tarihsel notlarla birlikte uygulamalar \\
\hline Öğrencinin okul dışı çalışmalarında yer alan tarihsel ögeler \\
Verilerin analizinden önce hangi ögenin matematik tarihi ögesi olup olmadığına karar \\
vermek için matematik tarihi ögesinin tanımının açıklanması ihtiyacı hissedilmiştir. Alan yazın \\
incelendiğinde Erdoğan vd. (2015) çalışmalarında matematik tarihi ögesini, matematik tarihinin \\
uğraş alanları ile ilgili açıkça bilgi taşıan nesneler bağlamında kullandıkları görülmektedir. Bu \\
bağlamda Şekil 1'deki türden ögeler matematik tarihi ögesi olarak kabul edilmemiştir.
\end{tabular}




\section{Bunu Deneyelim-2}

Gerekli Malzemeler : Kareli kağıt, renkli kalemler, not defteri

\begin{tabular}{|c|c|c|c|c|c|c|c|c|c|}
\hline 1 & 2 & 3 & 4 & 5 & 6 & 7 & 8 & 9 & 10 \\
\hline 11 & 12 & 13 & 14 & 15 & 16 & 17 & 18 & 19 & 20 \\
\hline 21 & 22 & 23 & 24 & 25 & 26 & 27 & 28 & 29 & 30 \\
\hline 31 & 32 & 33 & 34 & 35 & 36 & 37 & 38 & 39 & 40 \\
\hline 41 & 42 & 43 & 44 & 45 & 46 & 47 & 48 & 49 & 50 \\
\hline 51 & 52 & 53 & 54 & 55 & 56 & 57 & 58 & 59 & 60 \\
\hline 61 & 62 & 63 & 64 & 65 & 66 & 67 & 68 & 69 & 70 \\
\hline 71 & 72 & 73 & 74 & 75 & 76 & 77 & 78 & 79 & 80 \\
\hline 81 & 82 & 83 & 84 & 85 & 86 & 87 & 88 & 89 & 90 \\
\hline 91 & 92 & 93 & 94 & 95 & 96 & 97 & 98 & 99 & 100 \\
\hline
\end{tabular}

Yukarıdaki yüzlük tabloyu kullanarak,

- 2 sayısını mavi renkli kalem ile yuvarlak içine alınız. Daha sonra 2'nin katı olan tüm sayıların bulunduğu kutucukları sarı renkli kalem ile boyayınız.

- Bu işlemi işaretlenmeyen bir sonraki sayı için yapınız. Yani 3 sayısını mavi renkli kalem ile yuvarlak içine alınız. Daha sonra 3'ün katı olan tüm sayıların bulunduğu kutucukları sarı renkli kalem ile boyayınız.

- Bu işlemi işaretlenmeyen bir sonraki sayı için yapınız. Yani 5 sayısını mavi renkli kalem ile yuvarlak içine alınız. Daha sonra 5'in katı olan tüm sayıların bulunduğu kutucukları sarı renkli kalem ile boyayınız.

- Bu işleme tabloda ileriye doğru işaretlenmeyen sayı kalmayıncaya kadar devam ediniz,

- Yuvarlak içine aldığınız sayıları not ediniz.

* Bu sayıların ortak özelliği hakkında ne söyleyebilirsiniz?

Şekil 1. Tarihsel öge olarak kabul edilmeyen bir öge ( MEB Yayınları 6. sınıf, s.69)

Şekil 1 incelendiğinde asal sayıların belirlenmesi ile ilgili olarak verilen Eratosthenes Kalburu olarak bilinen etkinlik verilmiş fakat bu konuda hiçbir tarihi bilgiye yer verilmediği görülmüş̧ür.

Benzer şekilde Şekil 2'de verilen Goldbach'ın İddiası olarak yazılan bilgi notu da matematik tarihi ile ilgili herhangi bir bilgi vermediği için matematik tarihi ögesi olarak kabul edilmemiştir. 


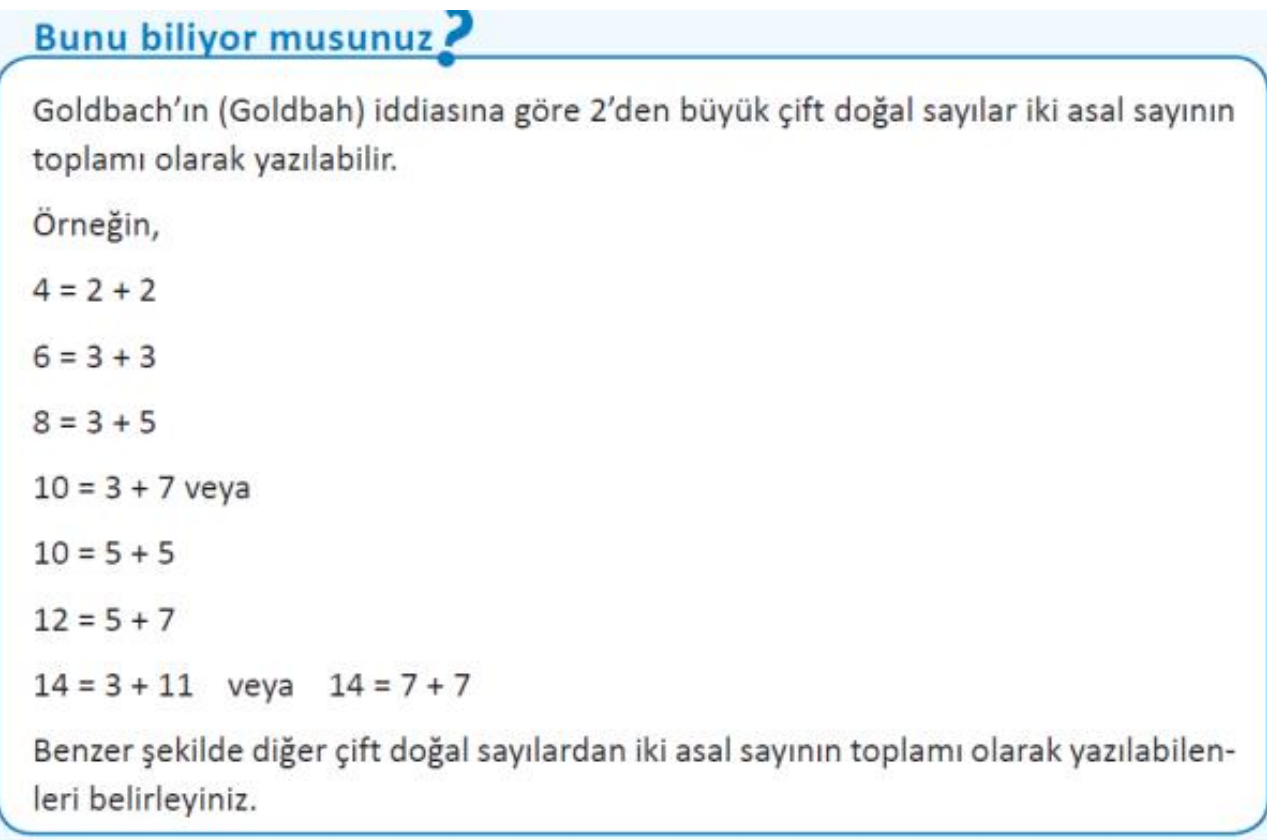

Şekil 2. Tarihsel öge olarak kabul edilmeyen bir öge ( MEB Yayınları 6. Sınıf, s.71)

Veri analizlerinin yapılış şeklinin daha açık belirtilmesi için bazı örnek kodlamalar aşağıda gösterilmiştir. Şekil 3'te 5.Sınıf MEB yayınları ders kitabından alınan bir matematik tarihi ögesi matematik tarihine ilişkin notların çeşitli örnek veya uygulamalarla birlikte açıklanması şeklinde kurgulandığı için, Erdoğan vd. (2015) yaptığı ekolojik analiz yöntemine göre incelendiğinde "tarihsel notlarla birlikte uygulamalar" olarak kodlanmıştır. Yine aynı örnek, Tzanakis ve Archavi’nin (2000) önerdiği analize göre, tarihsel ufak parçalar olarak kodlanmıştır.

Bunu biliyor musunuz?

Avrupa'da, Orta Çağ'a kadar Roma rakamları kullanılmaktaydı. Ancak Roma rakamlarında sıfır olmadığından, kâğıt kalem kullanarak dört işlem yapmak oldukça zordu. Bu rakamlarla işlem yapmak için özel araçlar kullanılması gerekiyordu ve bu araçları genelde ticaretle uğraşanlar kullanabiliyordu. Eskiden dört işlem yapmanın bu kadar zor olduğunu biliyor muydunuz?

Aşağıda 14 × 61 işleminin Roma rakamlarıyla yapılışı görülmektedir. Tabloda Roma rakamlarıyla yazılan sayıların bugünkü değerleri yanlarında verilmiştir. İşlemin nasıl yapıldığını anladınız mı?

\begin{tabular}{c|c|c|c} 
& 14 & 61 & \\
\hline 14 & XIV & U* & 64 \\
\hline 7 & VII & CXII & 112 \\
\hline 3 & III & CCXXIV & 224 \\
\hline 1 & I & CDXLVIII & 448 \\
\hline \multicolumn{4}{|c}{ \pm} \\
\cline { 3 - 4 }
\end{tabular}

Şekil 3. Tarihsel notlarla birlikte uygulamalar ve tarihsel ufak parçalara örnek 
Şekil 4'te 6. Sınıf MEB yayınları ders kitabından alınan bir matematik tarihi ögesinin, Erdoğan vd. (2015) yaptığı ekolojik analiz yöntemine göre tarihler, biyografiler, anekdotlar, sembollerin ve kelimelerin kökeni gibi bilgilerin verildiği notlar olduğu için, tarihsel notlar olarak kodlanmıştır. Yine aynı örnek, Tzanakis ve Archavi (2000)'nin önerdiği analize göre, tarihsel ufak parçalar olarak kodlanmıştır.

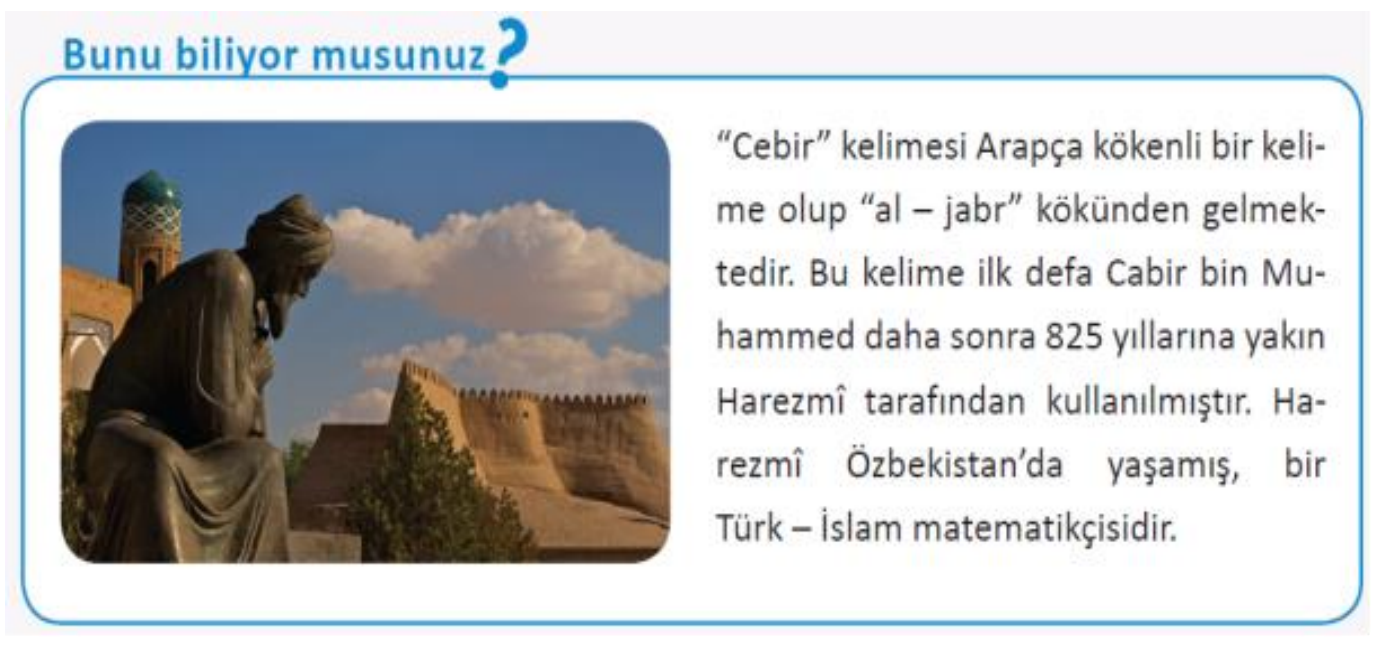

\section{Şekil 4. Tarihsel notlar ve tarihle ufak parçalara örnek kodlamalar}

Şekil 5'te 6. Sınıf Sevgi Yayınları ders kitabından alınan bir matematik tarihi ögesinin, Erdoğan vd. (2015) yaptığı ekolojik analiz yöntemine göre matematik tarihi içeren projeler, performans görevleri gibi okul dışı çalışmalara yönelik olduğu için öğrencinin okul dışı çalışmalarında yer alan tarihsel ögeler olarak kodlanmıştır. Yine aynı örnek, Tzanakis ve Archavi (2000)'nin önerdiği analize göre, internet olarak kodlanmıştır.

\section{PROJE GÖREVI}

\section{Kesirlerle İșlemler}

Yönerge: MÖ VI. yũzyılda yaşamış olan Yunan filozof ve matematikçi Pisagor (Pythagoras) modern aritmetiğin temellerini atmıştır. Pisagor tablosu olarak da bilinen çarpım tablosunu oluşturmuştur.

Sizden kesirlerle işlem yapmayı gōsteren bir dergi hazırlamanız ve bu aşamaları raporlamanız isteniyor.

Şekil 5. Öğrencinin okul dışı çalışmalarında yer alan tarihsel ögeler ve internete örnek kodlama 


\section{Bulgular}

Tablo 4'de ortaokul matematik ders kitaplarında yer verilen matematik tarihi ile ilgili ögelerin içeriklerinin sınıf seviyelerine ve yayınevlerine göre dağılımları verilmiştir.

Tablo 4. Ders kitaplarında yer alan matematik tarihi ögelerinin içeriklerine göre dağılımı

\begin{tabular}{|c|c|c|c|c|c|c|c|}
\hline \multirow{2}{*}{ Kategoriler } & \multicolumn{2}{|c|}{ 5. Sinif } & \multicolumn{2}{|l|}{ 6. Sinif } & \multirow{2}{*}{$\begin{array}{l}\text { 7. Sinif } \\
\text { Ada }\end{array}$} & \multirow{2}{*}{$\begin{array}{l}\text { 8. Sinif } \\
\text { Sevgi }\end{array}$} & \multirow{2}{*}{ Toplam } \\
\hline & MEB & Özgün & MEB & Sevgi & & & \\
\hline Tarihsel notlar & 3 & 0 & 3 & 0 & 0 & 1 & 7 \\
\hline $\begin{array}{l}\text { Matematiğin } \\
\text { kullanım alanlarına } \\
\text { ilişkin notlar }\end{array}$ & 0 & 0 & 0 & 0 & 1 & 0 & 1 \\
\hline $\begin{array}{l}\text { Tarihsel notlarla } \\
\text { birlikte uygulamalar }\end{array}$ & 3 & 1 & 1 & 1 & 0 & 0 & 6 \\
\hline $\begin{array}{l}\text { Öğrencinin okul dışı } \\
\text { çalışmalarında yer } \\
\text { alan tarihsel ögeler }\end{array}$ & 0 & 0 & 0 & 1 & 0 & 0 & 1 \\
\hline Toplam & 6 & 1 & 4 & 2 & 1 & 1 & 15 \\
\hline
\end{tabular}

Tablo 4. incelendiğinde 5. Sınıf MEB yayınlarının 6 adet matematik tarihi ögesinin 3 tanesinin tarihsel notlar diğer üçünün ise tarihsel notlarla birlikte uygulamalar alanında yer aldığı görülmektedir. 5. Sınıf Özgün Yayınlarında ise 1 tane olan ögenin tarihsel notlarla birlikte uygulamalar kısmında yer aldığı görülmüştür. 6. Sınıf MEB yayınlarında 4 tane olan ögenin 3 tanesi tarihsel notlar kısmında 1 tanesi tarihsel notlarla birlikte uygulamalar kısmında yer almaktadır. 6. Sınıf Sevgi Yayınlarında ise 2 tane olan ögenin 1 tanesi tarihsel notlarla birlikte uygulamalar kısmında 1 tanesi ise öğrencinin okul dışı çalışmalarında yer alan tarihsel ögeler kısmında yer almaktadır. Ayrıca bu öge, ortaokul matematik ders kitaplarının içinde bu kısımda yer alan tek ögedir. 7. Sınıf Ada Yayınlarında olan 1 adet öge matematiğin kullanım alanlarına ilişkin notlar kısmında yer almaktadır. Yine Tablo 4'den de görülebileceği gibi matematiğin kullanım alanlarına ilişkin sadece 1 tane matematik tarihi ögesi vardır. Öğrencilerin matematiğin kullanım alanlarını, günlük hayatla ilişkilendirmeye çalıştıkları ve günlük hayattaki işlevini sorguladıkları bir çağda 6 ders kitabında bu alanda 1 tane matematik tarihi ögesi olması dikkat çekicidir. 8. Sınıf Sevgi Yayınlarında var olan 1 adet öge ise tarihsel notlar kısmında yer almaktadır. Tablo 4ye bakıldığında ders kitaplarında yer alan toplam 15 adet matematik tarihi ögesinin 7 tanesinin tarihsel notlar, 6 tanesinin ise tarihsel notlar ile birlikte uygulamalar kısmında yer aldığı görülebilir. Yani toplam öge sayısının neredeyse tamamı, matematik tarihi ile ilgili kısa bilgiler veya kısa uygulamalar içeren notlardan oluşmaktadır.

Tablo 5'te ortaokul matematik ders kitaplarında yer verilen matematik tarihi ile ilgili ögelerin matematik tarihinin kullanımına yönelik sınıflamaların sınıf seviyelerine ve yayınevlerine göre dağılımı gösterilmiştir. 
Tablo 5. Ders kitaplarında yer alan matematik tarihi ögelerinin kullanım yollarına göre dağılımı

\begin{tabular}{|c|c|c|c|c|c|c|c|}
\hline Kategoriler & $\begin{array}{l}\text { 5. Sinif } \\
\text { MEB }\end{array}$ & Özgün & $\begin{array}{l}\text { 6. Sinif } \\
\text { MEB }\end{array}$ & Sevgi & $\begin{array}{l}\text { 7. Sinif } \\
\text { Ada }\end{array}$ & $\begin{array}{l}\text { 8. Sinıf } \\
\text { Sevgi }\end{array}$ & Toplam \\
\hline Tarihsel ufak parçalar & 6 & 1 & 4 & 0 & 1 & 1 & 13 \\
\hline $\begin{array}{l}\text { Deneysel matematik } \\
\text { etkinlikleri }\end{array}$ & 0 & 0 & 0 & 1 & 0 & 0 & 1 \\
\hline İnternet & 0 & 0 & 0 & 1 & 0 & 0 & 1 \\
\hline Çalışma yaprakları & 0 & 0 & 0 & 0 & 0 & 0 & 0 \\
\hline Tarihsel paketler & 0 & 0 & 0 & 0 & 0 & 0 & 0 \\
\hline Tarihsel problemler & 0 & 0 & 0 & 0 & 0 & 0 & 0 \\
\hline Mekanik araçlar & 0 & 0 & 0 & 0 & 0 & 0 & 0 \\
\hline $\begin{array}{l}\text { Tarihsel metinler } \\
\text { üzerine dayalı } \\
\text { araştırma projeleri }\end{array}$ & 0 & 0 & 0 & 0 & 0 & 0 & 0 \\
\hline Oyunlar & 0 & 0 & 0 & 0 & 0 & 0 & 0 \\
\hline $\begin{array}{l}\text { Filmler ve Diğer } \\
\text { görseller }\end{array}$ & 0 & 0 & 0 & 0 & 0 & 0 & 0 \\
\hline Okul dışı deneyimleri & 0 & 0 & 0 & 0 & 0 & 0 & 0 \\
\hline Birincil kaynaklar & 0 & 0 & 0 & 0 & 0 & 0 & 0 \\
\hline $\begin{array}{l}\text { Matematikçilerin } \\
\text { yaptıkları hatalardan } \\
\text { yararlanma }\end{array}$ & 0 & 0 & 0 & 0 & 0 & 0 & 0 \\
\hline Toplam & 6 & 1 & 4 & 2 & 1 & 1 & 15 \\
\hline
\end{tabular}

Tablo 5'te görüldüğü gibi 15 tane olan matematik tarihi ögesinin 13 tanesinin tarihsel ufak parçalar şeklinde kullanıldığı, 1 tanesinin deneysel matematik etkinlikleri şeklinde kullanıldığı, 1 tanesinin ise öğrenciyi araştırmaya yönlendiren internet taraması şeklinde kullanıldığı görülmektedir. Ders kitaplarında kullanılan matematik tarihi ögelerinin sayısının az olmasının yanı sıra çeşitliliğinin de az olduğu dikkat çekmektedir.

Tablo 6'da ortaokul matematik ders kitaplarında yer alan matematik tarihi ile ilgili ögelerin kitaplardaki konumlarının sınıf seviyelerine ve yayınevlerine göre dağılımı gösterilmiştir. 
Ortaokul Matematik Ders Kitaplarında Yer Verilen Matematik Tarihi İçeriklerinin İncelenmesi

Tablo 6. Ders kitaplarında yer alan matematik tarihi ögelerinin kitaplardaki konumlarına göre dağılımı

\begin{tabular}{|c|c|c|c|c|c|c|c|}
\hline \multirow{2}{*}{ Kitaplardaki Konumlar } & \multicolumn{2}{|c|}{ 5. Sinif } & \multicolumn{2}{|c|}{ 6. Sinif } & \multirow{2}{*}{$\frac{\text { 7. Sinif }}{\text { Ada }}$} & \multirow{2}{*}{$\begin{array}{l}\text { 8. Sinıf } \\
\text { Sevgi }\end{array}$} & \multirow{2}{*}{ Toplam } \\
\hline & MEB & Özgün & MEB & Sevgi & & & \\
\hline Konuya Giriş & 0 & 0 & 0 & 1 & 1 & 1 & 3 \\
\hline Konu İçinde & 3 & 1 & 3 & 1 & 0 & 0 & 8 \\
\hline $\begin{array}{l}\text { Değerlendirme ve } \\
\text { Konu Sonu }\end{array}$ & 3 & 0 & 1 & 0 & 0 & 0 & 4 \\
\hline Toplam & 6 & 1 & 4 & 2 & 1 & 1 & 15 \\
\hline
\end{tabular}

Ders kitaplarında kullanılan matematik tarihi ögelerinin kitaplardaki konumlarına göre sinıflandırılmasının yapıldığı Tablo 6 incelendiğinde kitaplarda bulunan toplam 15 adet ögenin 3 tanesinin konuya giriş kısmında, 8 tanesinin konu içinde, 4 tanesinin ise konunun değerlendirmesi ve konu sonu kısmında yer almaktadır. Konunun giriş kısmında kullanılan matematik tarihi öge sayısının az olması ise, ders kitaplarında öğrencilerin ilgisini ve dikkatini konuya çekmek, öğrencinin derse güdülenmesini sağlamak amacıyla matematik tarihinden yeteri kadar faydalanılmadığı görülmektedir.

Tablo 7'de ortaokul matematik ders kitaplarında yer alan matematik tarihi ögelerinin öğrenme alanlarına göre dağılımı sınıf seviyesi ve yayınevlerine göre verilmiştir.

Tablo 7. Ders kitaplarında yer alan matematik tarihi ögelerinin öğrenme alanlarına göre dağılımı

\begin{tabular}{|c|c|c|c|c|c|c|c|}
\hline \multirow{2}{*}{ Öğrenme Alanları } & \multicolumn{2}{|c|}{ 5. Sinif } & \multicolumn{2}{|c|}{ 6. Sinif } & \multirow{2}{*}{$\begin{array}{l}\text { 7. Sinıf } \\
\text { Ada }\end{array}$} & \multirow{2}{*}{$\begin{array}{l}\text { 8. Sinif } \\
\text { Sevgi }\end{array}$} & \multirow{2}{*}{ Toplam } \\
\hline & MEB & Özgün & MEB & Sevgi & & & \\
\hline Sayılar ve İşlemler & 5 & 1 & 0 & 2 & 1 & 0 & 9 \\
\hline Cebir & 0 & 0 & 3 & 0 & 0 & 0 & 3 \\
\hline Geometri ve Ölçme & 0 & 0 & 1 & 0 & 0 & 1 & 2 \\
\hline Veri işleme & 1 & 0 & 0 & 0 & 0 & 0 & 1 \\
\hline Olasıl11k & 0 & 0 & 0 & 0 & 0 & 0 & 0 \\
\hline Toplam & 6 & 1 & 4 & 2 & 1 & 1 & 15 \\
\hline
\end{tabular}

5. Sınıf matematik ders kitaplarında değişen ortaokul müfredatı gereği olasılık ve cebir öğrenme alanı dışında üç öğrenme alanından konular vardır. 5.Sınıf matematik ders kitaplarında bulunan matematik tarihi ögelerinin öğrenme alanlarına göre sınıflandırılması yapıldığında MEB yayınlarında bulunan 6 matematik tarihi ögesinin 5'inin sayılar ve işlemler öğrenme alanından olduğu görülmektedir. Yine 5. Sınıf Özgün Yayınlarına bakıldığında bulunan tek matematik tarihi ögesinin sayılar ve işlemler öğrenme alanında olduğu görülmektedir. Buradan 5. Sınıf matematik ders kitaplarında bulunan matematik tarihi ögelerinin sayılar ve işlemler öğrenme alanına yığıldığı söylenebilir. Farklı bir öğrenme alanında ise sadece 5. Sınıf MEB yayınlarında veri işleme öğrenme alanında 1 matematik tarihi ögesine rastlanmıştır.

6. Sınıf matematik ders kitaplarında değişen ortaokul müfredatı gereği olasılık öğrenme alanı dışında diğer dört öğrenme alanından konular vardır. 6. Sınıf matematik ders kitaplarında 
bulunan matematik tarihi ögelerinin öğrenme alanlarına göre sınıflandırılması yapıldığında MEB yayınlarında bulunan 4 matematik tarihi ögesinin üçünün cebir alanında olduğu 1 tanesinin geometri ve ölçme alanında olduğu görülmektedir. Sayılar ve işlemler ile veri işleme alanında ise matematik tarihi ögesine rastlanmamıştır. Sevgi Yayınlarına ait matematik ders kitabında ise 2 tane olan matematik tarihi ögesinin ikisinin de sayılar ve işlemler öğrenme alanında olduğu görülmüştür. Ders kitaplarında yer alan matematik tarihi ögelerinin sayılarının yetersiz olmakla birlikte farklı kitaplarda farklı öğrenme alanlarında yoğunlaştı̆̆ı söylenebilir.

7. Sınıf matematik ders kitabında değişen ortaokul müfredatı gereği olasılık öğrenme alanı dışında diğer dört öğrenme alanından konular vardır. 7. Sınıf matematik ders kitabında bulunan matematik tarihi ögelerinin öğrenme alanlarına göre sınıflandırılması yapıldığında 1 tane olan matematik tarihi ögesinin sayılar ve işlemler öğrenme alanında olduğu gözlenmiştir. Burada 7. Sınıf müfredatında cebir öğrenme alanının kapladığı alan düşünüldüğünde hiç matematik tarihi ögesinin olmaması dikkat çekicidir.

8. Sınıf matematik ders kitabında değiş̧en ortaokul matematik öğretim programına göre bütün öğrenme alanları mevcuttur. 8. Sınıf matematik ders kitabında ise 1 tane olan matematik tarihi ögesinin geometri ve ölçme alanında olduğu görülmektedir. Yine 8. Sınıf müfredatında cebrin kapladığı yer, olasılığın ilk defa görülüyor olması ve irrasyonel sayıların ilk defa bu sınıfta görülüyor olmasına rağmen bu öğrenme alanlarında matematik tarihi ögesine yer verilmemesi dikkat çekicidir.

\section{Tartışma ve Sonuç}

Türkiye'de ortaokul düzeyinde okutulmakta olan matematik ders kitaplarında matematik tarihi ögelerinin içeriklerinin ve kullanım yollarının belirlenmesiyle ilişkin yapılan araştırma sonucunda öncelikle kullanılan öge sayısının az olduğu sonucuna ulaşılmıştır. Toplamda 15 adet matematik tarihi ile ilişki öge bulunmuş olup incelenen kitap sayısına bölündügünde, kitap başına 2,5 öge bulunduğu saptanmıştır. Her kitapta en az bir öge bulunduğu göz önünde bulundurulursa bu değerin oldukça az olduğu söylenebilir. Bu durum ortaokul matematik ders kitabı hazırlamada matematik tarihinden ziyade matematik ile ilgili salt bilgi ve uygulama vermenin tercih edildiği şeklinde yorumlanabilir. Her ne kadar sürekli yenilenen matematik öğretim programlarının matematiği somut öğretim araç-gereçleri ile daha anlamlı öğretmeyi hedeflediği (MEB, 2017) belirtilse de kitap yazarlarında okul matematiğinde matematik tarihi kullanımına yönelik tutum ve inanışlarının henüz yeterince olgunlaşmamış olması muhtemeldir. Bu sayı diğer benzer çalışmalarda bulunan sayılardan daha düşük durumdadır. Örneğin Erdoğan vd. (2015) çalışmasında incelen ders kitapları başına 4 matematik tarihi ögesi saptanmıştır. Benzer şekilde Thomaidis ve Tzanakis (2009)'in Yunan kitaplarını incelediği çalışmada ise toplamda 35, ders kitabı başına ise 12,3 öge bulunmuşken, Smestad (2000)'in çalışmasında Norveç kitaplarında kitap başına 8,8 öge bulunmuştur. Bu durum Türkiye'deki ders kitabı hazırlamada matematik tarihi üzerine vurgunun düşük düzeyde kaldığını göstermektedir.

Matematik tarihi ögelerinin öğrenme alanlarına göre dağılımlarına bakıldığında tespit edilen 15 ögenin 9'unun sayılar ögrenme alanında olduğu bulunmuştur. Bu sonuç ile Erdoğan vd.'nin (2015) yaptığı çalışma ile benzerlik göstermektedir. O çalışmada da tespit edilmiş olan 27 ögenin 14'ü sayılar öğrenme alanı ile ilişkilidir. Erdoğan vd.(2015) çalışmalarında 2013 2014 yılında okutulan kitapları incelemiştir ve araştırmanın sonuçlarında matematik ders kitaplarında matematik tarihi kullanımını yetersiz olarak göstermişlerdir. Mevcut çalışmanın 
bahsi geçen çalışmadan 3 sene sonra yapıldığ 1 göz önünde bulundurulursa 3 yılda kitaplarda matematik tarihi kullanım tercihinde büyük bir değişim görülmediği anlaşılmaktadır. 2013 2014 yılında 5.Sınıf düzeyinde MEB tarafından yayınlanan kitapta tespit edilen 7 ögenin 5'i sayılar öğrenme alanında iken, mevcut çalışmada 2016 - 2017 yılında 5. Sınıf MEB kitabında tespit edilen 6 ögenin 5'i aynı öğrenme alanındadır. Bu dönem içinde eğitim sisteminin değişimi ve buna bağlı müfredatın yenilenmesi de özellikle 5. Sınıf düzeyi için hazırlanan kitapta matematik tarihi kullanımında bir değişim meydana getirmediği söylenebilir.

Her ne kadar geometri ve ölçme konularının tarihi sayılar kadar eski sayılabilirse de bu konular hakkında yeteri kadar matematik tarihi unsuru incelenen kitaplarda rastlanmamıştır (15 ögenin 1 tanesi 5. Sınıf, 1 tanesi 8. Sınıf düzeyindedir). Baki ve Bütüner (2013) çalışmalarında inceledikleri 2011 - 2012 öğretim yılında okutulan 6.,7. ve 8. Sınıf ders kitaplarında tespit ettikleri 19 matematik tarihi ögesinin de sadece 3 tanesi geometri ve ölçme ile ilişkilidir. Bu durum da, yukarıda belirtildiği gibi yıllar içerisinde hazırlanan ders kitaplarına matematik tarihi bağlamında bir değişimin olmadığını yeniden göstermektedir.

Mevcut çalışmada tespit edilmiş olan unsurların konuların aktarım sırasına göre dağılımında ise kitaplarda kullanılan matematik tarihi ögelerinin daha çok konunun öğretiminde, öğrenciye öğrendikleri konunun daha eskiden nasıl yapıldığııı göstermek, konunun öğretimi için farklı uygulamalar yaptırmak amacıyla kullanıldığı söylenebilir. Bu durum Baki ve Bütüner (2013) yapmış olduğu çalışma ile farklılıklar oluşturmaktadır. Baki ve Bütüner (2013)'in çalışmasında tespit edilen matematik tarihi ögelerinin neredeyse tamamı (19 ögenin 18 tanesi) konu başlangıcında yer almaktadır. Böylece 2011'den günümüze matematik tarihinin sadece konuya başlarken ilgi çekmek amaciyla yapmaktan vazgeçildiği olarak yorumlanabilir.

Bununla birlikte, teknolojinin hızla ve durmadan geliştiği günümüzde internet kaynaklı matematik tarihi ögelerine ulaşmada öğrencilere yol gösterici olabilecek kaynakların ders kitaplarında neredeyse hiç yer almadığı görülmüştür. Sadece 6. Sınıf özel yayınevinde 1 adet öge ders kitaplarına konulmuştur. Doğruluk derecesi saptanmış internet üzerinde yer alan matematik tarihi bilgilerine ders kitaplarında referans gösterilmesi matematik eğitiminin ilgi çekiciliğini de arttıracaktır. İleriki çalışmalarda kullanılmak üzere son dönemde okullarda kullanılan EBA içeriklerinin matematik tarihi bakımından incelenmesi ve ayrıca öğretim sürecinde matematik tarihi ögelerinin kullanımına yönelik içerik geliştirilmesi önerilmektedir. 


\section{Kaynakça}

Albayrak, Ö. (2011). Effects of history of integrated instruction on mathematics self-efficacy and achievement. Yayınlanmamış Yüksek Lisans Tezi.

Alkan, C. (1979). Eğitim ortamları. Ankara Üniversitesi Eğitim Bilimleri Fakültesi Yayınları No:85, Ankara.

Baki, A. (2008). Kuramdan uygulamaya matematik eğitimi. Ankara: Harf Eğitim Yayıncılık.

Baki, A. (2014). Matematik tarihi ve felsefesi. Pegem: Ankara.

Baki, A. \& Bütüner, S. Ö. (2013). 6, 7 ve 8. sınıf matematik ders kitaplarında matematik tarihinin kullanım şekilleri. İlkögretim Online, 12(3), 849-872.

Dursun, Ş. ve Dede, Y. (2004). Öğrencilerin matematikte başarısını etkileyen faktörler: matematik öğretmenlerinin görüşleri bakımından. Gazi Eğitim Fakültesi Dergisi, 24(2), 217-230.

Erdoğan, A., Eşmen, E., \& Fındık, S. (2015). Ortaokul matematik ders kitaplarında matematik tarihinin yeri: ekolojik bir analiz. Marmara Üniversitesi Atatürk Eğitim Fakültesi Eğitim Bilimleri Dergisi. 2015, 42-08.

Guillen, M. (2010). Dünyayı değiştiren beş denklem, matematiğin gücü ve şiirselliği. 12. Baskıdan Çev.Tanrı̈ver, G. Tübitak: Ankara.

Gulikers, I. \& K. Blom, (2001). A historical angle ee a survey of recent literature on the use and value of history in geometrical education, Educational Studies in Mathematics, 47, 223-258.

Gürsoy, K. (2010). İlköğretim matematik öğretmen adaylarının matematik tarihinin matematik öğretiminde kullanılmasına yönelik ilişkin inanç ve tutumlarının incelenmesi.Yayınlanmış Yüksek Lisans Tezi.

Jankvist, T. (2009). A categorization of the "whys" and "hows" of using history in mathematics education. Educational Studies in Mathematics, 71, 235-261.

Koçyiğit, A., ve Pektaş, M. (2017). Ortaokul Fen Bilimleri Ders Kitaplarındaki Okuma Parçalarının Bilim Tarihi Kullanımı Açısından İncelenmesi. Cumhuriyet International Journal of Education, 6(1), 185199.

Liu, H. 2003. Do teachers need to incorporate the history of mathematics in their teaching?, Connecting Research to Teaching, 96, 6, 416-421.

Marshall, L.G. (2000). Using history of mathematics to improve secondary students attitudes toward mathematics, unpublished doctoral thesis, Illinois State University, USA.

MEB, 2013. İlköğretim 5-8. sinıflar matematik öğretim programı. http://ttkb.meb.gov.tr/www/ogretimprogramlari/icerik/72

Nasibov, F., \& Kaçar, A. (2005). Matematik ve matematik eğitimi üzerine. Kastamonu Eğitim Dergisi Cilt 13, No 2 , 339-346.

NCTM (National Council of Mathematics), 1998, Historical topics for the mathematics classroom, Reston Publishing, Reston, VA.

Özgün-Koca, S.A. ve Şen, A.İ. (2006). Ortaöğretim öğrencilerinin matematik ve fen derslerine yönelik olumsuz tutumlarının nedenleri. Eurasian Journal of Educational Research, 23, 137-147.

Rosa, D.(2013). Intergrating history of mathematics into the mathematics classroom. Illions State University, Mathematics Education

Sertöz, S. (2002). Matematiğin aydınlık dünyası (16. Baskı), Tübitak: Ankara.

Shara, J.(2013). Benefits from intergrating history of mathematics into teaching. University Eqrem Cabej Faculty Of Natural Sciences Department Of Mathematics And Computer Sciences. 
Siu, M. K . ve Tzanakis, C..(2004). "History of mathematics in classroom teaching --- appetizer? Main course? Or dessert?". Excerpt from Mediterranean Journal for Research in Mathematics Education, Volume 3, No. 1-2 (2004).

Smestad, B. (2000). History of mathematics in norwegian textbooks. Ninth International Congress on Mathematical Education (ICME-9), Working Group For Action-13, Tokyo.

Swetz, F. (1994). Learning activities from the history of mathematics. The United States of America: J. Weston Walch, Publisher.

Thomaidis, Y. \& Tzanakis, C. (2009). The implementation of the history of mathematics in the new curriculum and textbooks in greek secondary education. Proceedings of CERME 6 (Congress of The European Society For Research in Mathematics Education), 2801-2810, Lyon.

Tözluyurt, E. (2008). Sayılar öğrenme alanı ile ilgili matematik tarihinden seçilen etkinliklerle yapılan dersler hakkında lise son sınıf ögrencilerinin görüşleri. Yayınlanmamış Yüksek Lisans Tezi, Gazi Üniversitesi, Eğitim Bilimleri Enstitüsü, Ankara.

Tzanakis, C. ve Arcavi, A., 2000. Integrating history of mathematics in the classroom: an analytic survey, in J. Fauvel, and J. Van Maanen (eds.), History in Mathematics Education, 201 - 240, Netherlands, Kluwer Academic Publishers.

Yalın, H.(1996). Ders kitaplarının değerlendirilmesi. 6. Milli Eğitim Sempozyumu, Kütahya, 4-5 Ekim.

Yenilmez, K. (2011). Matematik öğretmeni adaylarının matematik tarihi dersine ilişkin düşünceleri. Pamukkale Üniversitesi Eğitim Fakültesi Dergisi, 30(2), 79-90.

Yıldırım, C. (2008). Matematiksel düşünme. 5. Baskı, Remzi: İstanbul.

Yıldırım, A. \& Şimşek, H. (2006). Sosyal bilimlerde nitel araştırma yöntemleri. Ankara: Seçkin Yayıncilik.

Yıldız, C., Kanbolat, O. ve Baki, A. (2010). Ilköğretim matematik ögretmen adaylarının matematik tarihine yönelik düşünceleri. 9. Matematik Sempozyumu, Karadeniz Teknik Üniversitesi, Trabzon.

Wilson, P.S. ve Chauvot, J.B., 2000. Who? How? What? A strategy for using history to teach mathematics, Mathematics Teacher, 93, 8, 642-645. 


\section{Extended Abstract}

\section{Introduction}

In many countries the importance given to mathematics education is high and students are expected to be skilled in terms of their mathematical knowledge as well as in terms of analysis, synthesis, critical thinking and innovative thinking (Yıldırım 2008; Baki, 2008). Despite this fact, students think that mathematics cannot be related to everyday life. Many researchers state that the history of mathematics may be used as way to change the students' attitude (Rosa, 2013; Shara, 2013; Swetz, 1994; Gulikers ve Blom, 2001; Gürsoy, 2010; Liu, 2003; Marshall, 2000; NCTM, 1998; Y1ldı, Kanbolat ve Baki, 2010; Jankvist, 2009; Siu \& Tzanakis, 2004; Nasibov \& Kaçar, 2005). As textbooks are primary resources for students to gain information on the history of mathematics, the aim of this study is to analyze the mathematical history items in the secondary school mathematics textbooks, which are planned to be taught by the Ministry of National Education in 2016-2017 academic year, by two different ways and classify these items by examining the mathematical history items in the textbooks from various perspectives.

\section{Method}

Since the main purpose of the study is to make and explain the examination of the textbooks, content analysis which is one form descriptive analysis approaches is determined as the methodology of the study. In the document analysis, the 5Th, 6Th, 7Th and 8Th grade elementary school mathematics textbooks that the Ministry of Education has approved for 20162017 academic year have been examined. In the analysis of the data, the classification suggested by Tzanakis and Arcavi (2000) and the classification in accordance with the ecological analysis method proposed by Erdoğan, Eşmen and Fındık (2015) are used. The textbooks are examined by three experts and the obtained data are analyzed and classified.

\section{Findings, Discussion and Results}

According to findings of the study, a total of 15 items related to mathematical history were found, and there were 2.5 items per book. Considering that there is at least one item in each book, it can be concluded that this number is very low. When the distribution of the historical items of mathematics according to the learning areas is examined, it is found that 9 of the 15 items in the "numbers" learning field. Although the "geometry" and "measurement" topics may be regarded as historical as the "numbers" topic, there are not enough items in these learning areas ( 1 of 15 items in in 5th grade, 1 of them is in 8th grade). In the distribution of the items determined in the present study according to the instruction order of the subjects, it can concluded that the historical mathematical items in the textbooks are mostly used in teaching process the subject by showing to students how these subjects is taught in past. Meanwhile, as nowadays the way of developing technology and information is getting faster, resources that can guide students in reaching the internet-based mathematical elements are hardly ever found in textbooks. Only 1 item in the 6th grade textbook that is published by private company is included. Referencing the mathematical history information on the internet may increase the interest of students towards to mathematics. 